\title{
7T MRI of spinal cord injury
}

Figure $\quad$ 7T MRI

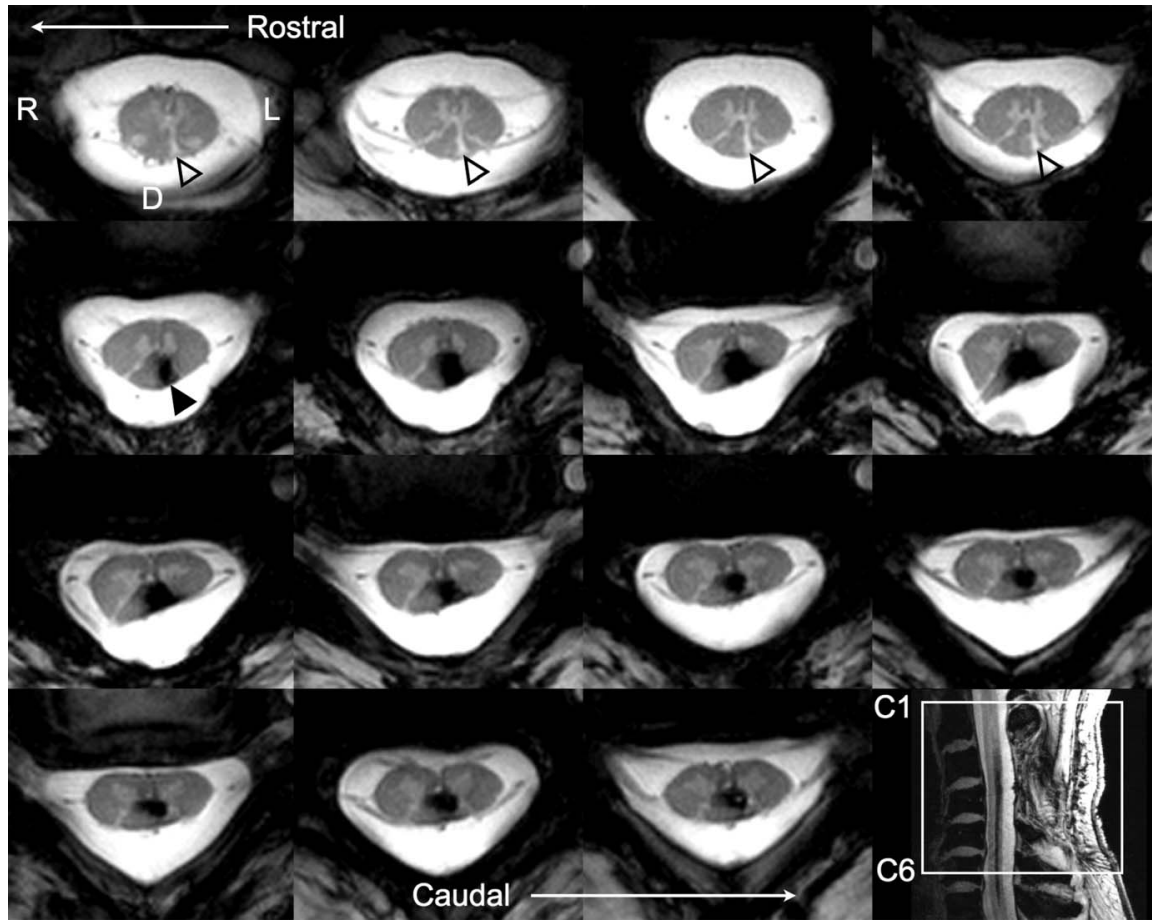

7T MRI with custom-made 19-channel coil (W. Zhao et al., Proceedings of the International Society for Magnetic Resonance in Medicine, 2012;310). Dual-echo T2*-weighted FLASH, repetition time $=514$ milliseconds, $534 \times 480$ matrix, $0.37 \times$ $0.37 \times 3 \mathrm{~mm}^{3}, \mathrm{R}=2$ acceleration, 4:24 minutes acquisition. At-level hyposignal (filled arrow) indicates hemosiderin whereas above-level hypersignal (empty arrows) suggests dorsal-column wallerian degeneration. Ultra-high resolution enables exquisite details of spinal cord anatomy including visualization of individual ventral/dorsal nerve roots.

A man with 25 years of mild left neck, arm, and leg paresthesias had initial MRI in 1996 identifying a left C3-4 dorsal horn cavernous hemangioma. In 1997, hemorrhage (C3-7) and resection induced left arm > leg proprioceptive loss and clumsiness. Three months after surgical resection, left upper-body pain recurred; 2 years later, disabling colocalizing itch recurred. ${ }^{1}$ In 2012, ultra-high-resolution 7T MRI (figure) localized hemosiderin to specific dorsal horn laminae and detected rostral (C1-3) hypersignal invisible on conventional MRIs, most likely representing wallerian degeneration. ${ }^{2}$ These new imaging findings demonstrate the benefit of high-field spinal cord MRI and generate the hypothesis that his late-onset central itch might be related to delayed white matter degeneration.

Julien Cohen-Adad, PhD, Wei Zhao, PhD, Lawrence L. Wald, PhD, Anne Louise Oaklander, MD, PhD, Boston, MA

Author contributions: Dr. Cohen-Adad: study concept and design, acquisition of data. Dr. Zhao: acquisition of data. Dr. Wald: study supervision. Dr. Oaklander: study concept and design.

Study funding: NIH-P41RR14075, NIH-K24NS59892, NIH-P41RR14075, NMSS-FG1892A1/1.

The authors report no disclosures relevant to the manuscript. Go to Neurology.org for full disclosures.

Correspondence and reprint requests to Dr. Cohen-Adad: jcohen@polymtl.ca

1. Dey DD, Landrum O, Oaklander AL. Central neuropathic itch from spinal-cord cavernous hemangioma: a human case, a possible animal model, and hypotheses about pathogenesis. Pain 2005;113:233-237.

2. Becerra JL, Puckett WR, Hiester ED, et al. MR-pathologic comparisons of wallerian degeneration in spinal cord injury. AJNR Am J Neuroradiol 1995;16:125-133. 


\title{
Neurology
}

\author{
7T MRI of spinal cord injury \\ Julien Cohen-Adad, Wei Zhao, Lawrence L. Wald, et al. \\ Neurology 2012;79;2217 \\ DOI 10.1212/WNL.0b013e31827597ae
}

This information is current as of November 26, 2012

\section{Updated Information \& Services}

\section{References}

Subspecialty Collections

Permissions \& Licensing

Reprints including high resolution figures, can be found at: http://n.neurology.org/content/79/22/2217.full

This article cites 2 articles, 0 of which you can access for free at: http://n.neurology.org/content/79/22/2217.full\#ref-list-1

This article, along with others on similar topics, appears in the following collection(s):

Diagnostic test assessment

http://n.neurology.org/cgi/collection/diagnostic_test_assessment_ MRI

http://n.neurology.org/cgi/collection/mri

Spinal cord trauma; see Trauma/spinal cord trauma

$\mathrm{http} / / / \mathrm{n}$.neurology.org/cgi/collection/spinal_cord_trauma-see_trauma-s pinal_cord_trauma

Spinal cord tumor

http://n.neurology.org/cgi/collection/spinal_cord_tumor

Information about reproducing this article in parts (figures,tables) or in its entirety can be found online at:

http://www.neurology.org/about/about_the_journal\#permissions

Information about ordering reprints can be found online:

http://n.neurology.org/subscribers/advertise

Neurology ${ }^{\circledR}$ is the official journal of the American Academy of Neurology. Published continuously since 1951, it is now a weekly with 48 issues per year. Copyright @ 2012 American Academy of Neurology. All rights reserved. Print ISSN: 0028-3878. Online ISSN: 1526-632X.

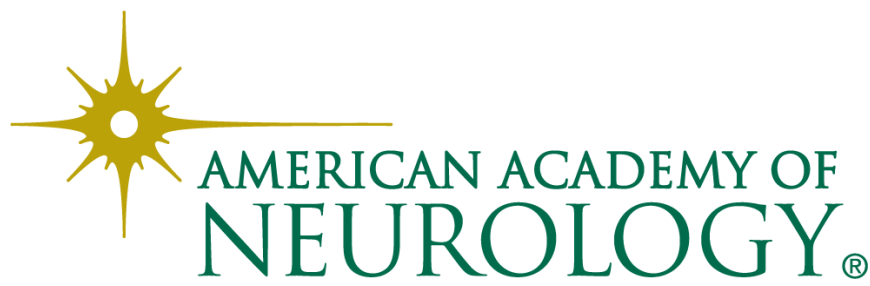

